\title{
Teknik Pemeriksaan Keabsahan Data pada Penelitian Kualitatif di Bidang Kesehatan Masyarakat
}

\author{
Arnild Augina Mekarisce \\ Program Studi Ilmu Kesehatan Masyarakat Fakultas Kedokteran dan Ilmu Kesehatan \\ Universitas Jambi
}

\begin{abstract}
Abstrak
Pendahuluan: Secara umum, penelitian diartikan sebagai rangkaian aktivitas keilmiahan yang terencana, terstruktur, sistematis, dan memiliki tujuan secara praktis dan teoritis, baik pada penelitian kuantitatif maupun kualitatif. Dikatakan terstruktur karena kegiatan ini berlangsung mengikuti suatu proses dan tahapan-tahapan tertentu. Salah satu tahapannya adalah tahapan dalam pengumpulan data. Data merupakan komponen yang krusial, sehingga dalam perjalanannya, data yang dikumpulkan harus memenuhi syarat pada pemeriksaan keabsahan data. Penelitian ini bertujuan untuk menjelaskan teori mengenai teknik pemeriksaan keabsahan data pada penelitian kualitatif di bidang kesehatan masyarakat.

Metode: Metode penelitian menggunakan literature review, yaitu literatur dikumpulkan dari beragam sumber data, seperti buku, artikel ilmiah, dan jurnal yang saling terkait.

Pembahasan: Teknik pemeriksaan keabsahan data merupakan salah satu unsur dalam penelitian kualitatif yang tidak dapat dipisahkan dari tubuh pengetahuan penelitian kualitatif di bidang kesehatan masyarakat. Teknik ini meliputi uji kredibilitas (perpanjangan pengamatan, peningkatan ketekunan, triangulasi, analisis kasus negatif, menggunakan bahan referensi, dan member check), transferabilitas, dependabilitas, maupun konfirmabilitas. Kesimpulan: Teknik pemeriksaan keabsahan data yang dapat dilakukan pada penelitian kualitatif di bidang kesehatan masyarakat yaitu dengan melakukan uji kredibilitas, transferabilitas, dependabilitas, maupun konfirmabilitas.
\end{abstract}

Kata kunci: kredibilitas, transferabilitas, triangulasi, dependabilitas, konfirmabilitas

\section{Data Validity Check Techniques in Qualitative Research in Public Health}

\begin{abstract}
Introduction: In general, the research method is defined as a scientific activity that is planned, structured, systematic, and has specific objectives both practical and theoretical, both in quantitative and qualitative research. It is said to be structured because this activity takes place following a certain process and stages. One of the stages is the stage in data collection. Data is very crucial in the research, so that in its journey, the data collected must meet the requirements on the validity of the data. This study aims to explain the theory about the data validity check techniques in qualitative research in public health.

Method: The method used is literature review, which is literature collected from various sources such as books, journals, scientific articles that are interrelated.

Result: Data Validity Check Techniques is an inseparable element of the body of qualitative research knowledge in the field of public health. Data validity checking techniques in this qualitative study include credibility tests (extended observations, increasing perseverance, triangulation, negative case analysis, using reference material, or holding a member check), transferability, dependability, and confirmability.

Conclusion: Data validity checking techniques that can be carried out in qualitative research in the field of public health are by conducting tests of credibility, transferability, dependability, and confirmability.

Keywords: credibility, transferability, triangulation, dependability, confirmability

\footnotetext{
Alamat Korespondensi:

Arnild Augina Mekarisce

Program Studi Ilmu Kesehatan Masyarakat

Fakultas Kedokteran dan Ilmu Kesehatan

Universitas Jambi

Email: augina@unja.ac.id
}

Jln. Letjend Soeprapto No. 33, Telanai Pura, Jambi
\end{abstract}




\section{PENDAHULUAN}

Secara epistemologis, penelitian merupakan rangkaian kegiatan ilmiah dalam rangka untuk menemukan jawaban atas permasalahan maupun pengetahuan baru. Penelitian selanjutnya dapat diklasifikasikan menjadi dua paradigma, yaitu penelitian kuantitatif dan penelitian kualitatif. Perbedaan paradigma ini tidak hanya mempengaruhi tujuan peneliti dalam memperoleh pengetahuan baru, tetapi juga mempengaruhi pemilihan metode dan peran peneliti, serta kriteria untuk menilai apakah sebuah penelitian berkualitas atau tidak berkualitas. ${ }^{1}$

Penelitian kuantitatif dan kualitatif memiliki perbedaan dalam masalah penelitian (research question). Penelitian kuantitatif menekankan pada pertanyaan -what, do, does, is, dan are," sedangkan penelitian kualitatif menekankan perhatian pada pertanyaan "how dan why". Contoh, berdasarkan data Riskesdas 2018, di Indonesia prevalensi merokok pada laki-laki sebesar $62,9 \%$ dan pada perempuan sebesar $4,8 \%$, jadi prevalensi merokok tinggi pada laki-laki. Terhadap fenomena itu, peneliti kuantitatif akan menekankan, apakah prediktor kebiasaan merokok? Apakah kebiasaan merokok berkaitan dengan tingkat pendidikan dan income? Seberapa besar kekuatan hubungan antara tingkat pendidikan dan kebiasaan merokok, serta apakah secara statistik signifikan? ${ }^{1,2}$

Di pihak lain, peneliti kualitatif akan menekankan pada pertanyaan mengapa orang mempunyai kebiasaan merokok? Bagaimana pola tipikal kebiasaan orang dalam merokok? Mengapa prevalensi merokok jauh lebih tinggi pada laki-laki dibandingkan perempuan? Karena pertanyaannya tentang "how dan why," bukan "what, do, does, is, are," maka penelitian kualitatif tidak mengenal pengujian hipotesis secara statistik, walaupun mengenal pengujian hipotesis. ${ }^{1}$

Qualitative reseacrh is a means for exploring and understanding the meaning individuals or groups ascribe to a social or human problem. The proccess of research involves emerging questions and procedures; collecting data in the participants setting; analyzing the data inductively, building from particulars to general themes; and making interpretations of the meaning of data. The final written report has a flexible writing structure. Adapun penelitian kualitatif merupakan suatu proses mengeksplorasi dan memahami pemaknaan atas perilaku yang dilakukan oleh individu dan kelompok, serta menggambarkan bagaimana terjadinya permasalahan dalam bidang sosial maupun kemanusiaan. Proses penelitian ini terdiri atas pertanyaan penelitian dan prosedur yang bersifat sementara, pengumpulan data, analisis data yang dilakukan secara induktif, mengkonstruksikan data parsial ke tema, kemudian menginterpretasikan makna data, dan kegiatan akhirnya yaitu menuliskan laporan. ${ }^{3}$

Metode kualitatif berkembang ketika terjadinya perubahan terhadap paradigma dalam memandang suatu realitas, fenomena, maupun gejala yang diamati. Saat terjadinya perubahan paradigma tersebut, realitas sosial telah dipandang dan dipahami sebagai hal yang holistik, kompleks, dinamis, dan penuh dengan pemaknaan. ${ }^{3,4}$

Penelitian kualitatif juga merupakan jenis penelitian yang menghasilkan penemuanpenemuan yang tidak dapat dicapai (diperoleh) oleh dengan menggunakan prosedur statistik atau cara-cara lain dari kuantifikasi (pengukuran), sehingga dapat digunakan untuk menemukan dan memahami apa yang tersembunyi dibalik fenomena yang merupakan sesuatu yang sulit untuk dipahami secara memuaskan. ${ }^{5}$

Karakteristik yang utama dalam penelitian kualitatif antara lain memfokuskan perhatian pada kondisi yang bersifat alamiah, langsung kepada sumber data (primer/sekunder), peneliti merupakan instrumen utama, penyajian data dapat berbentuk kata/gambar, tidak menekankan pada bentuk angka, lebih mengutamakan proses daripada produk/hasil, analisis data dilakukan secara induktif, serta menekankan pemaknaan di balik data yang diamati oleh peneliti. ${ }^{6}$

Peneltian kualitatif tidak memerlukan pengamatan pada seluruh anggota populasi, Penerapan penelitian kualitatif di bidang kesehatan masyarakat dapat dengan menggunakan beberapa informan untuk memahami proses yang terjadi berkaitan dengan fenomena penyakit, kesehatan, maupun perilaku terkait kesehatan, karena dengan adanya informasi yang kaya dari sejumlah kecil informan, peneliti kualitatif dapat mengeksplorasi dengan intens proses yang menjelaskan dan konteks yang melatarbelakangi fenomena yang terkait 
kesehatan yang menjadi perhatian peneliti. ${ }^{1}$

Peneliti yang merupakan instrumen utama pada penelitian kualitatif juga menunjukkan bahwa dalam penelitian kualitatif instrumennya adalah orang atau human instrument, maka peneliti di bidang kesehatan masyarakat juga harus mempunyai pemahaman teori dan wawasan yang luas untuk mendapatkan pandangan yang holistik atas konteks yang dikaji, karenanya harus memiliki kemampuan dalam bertanya, melakukan analisis, memotret, dan mengkonstruksi objek yang diteliti menjadi lebih jelas, rinci, dan penuh makna, terutama terkait teknik pemeriksaan keabsahan data dalam penelitian kualitatif di bidang kesehatan masyarakat. Hal ini penting untuk diperhatikan, karena data merupakan komponen yang krusial dalam penelitian, data inilah yang akan digunakan sebagai sumber analisis data, yang selanjutnya akan digunakan sebagai dasar dalam penarikan kesimpulan, sehingga data yang didapatkan harus memenuhi syarat keabsahan data. Penelitian ini bertujuan untuk menjelaskan teori mengenai teknik pemeriksaan keabsahan data pada penelitian kualitatif di bidang kesehatan masyarakat. ${ }^{3,7,8}$

\section{METODE}

Metode penelitian yang digunakan adalah literature review, yaitu literatur yang dikumpulkan dari beragam sumber seperti buku, artikel ilmiah, dan jurnal yang terkait dengan teknik pemeriksaan keabsahan data pada penelitian kualitatif di bidang kesehatan masyarakat.

\section{HASIL}

Teknik pemeriksaan keabsahan data tidak hanya digunakan untuk menyanggah apa yang telah dituduhkan kepada konsep penelitian kualitatif, yang mengatakan bahwa penelitian ini tidak bersifat ilmiah, tetapi teknik pemeriksaan keabsahan data ini merupakan sebagai tahapan yang tidak dapat dipisahkan dari tubuh pengetahuan pada penelitian kualitatif.

Teknik pemeriksaan keabsahan data pada penelitian kualitatif diantaranya yaitu uji kredibilitas, uji transferabilitas, uji dependabilitas, dan uji konfirmabilitas.

\section{PEMBAHASAN}

\section{Uji Kredibilitas (Credibility)}

Dalam penelitian kuantitatif, kredibilitas disebut validitas internal. Dalam penelitian kualitatif, data dapat dinyatakan kredibel apabila adanya persamaan antara apa yang dilaporkan peneliti dengan apa yang sesungguhnya terjadi pada objek yang diteliti. Ketika di lapangan ditemukan bahwa terdapat kekurangan tenaga kesehatan di lingkungan rumah sakit, maka permasalahan kekurangan tenaga kesehatan inilah yang akan dieksplorasi informasinya oleh peneliti lebih detail,

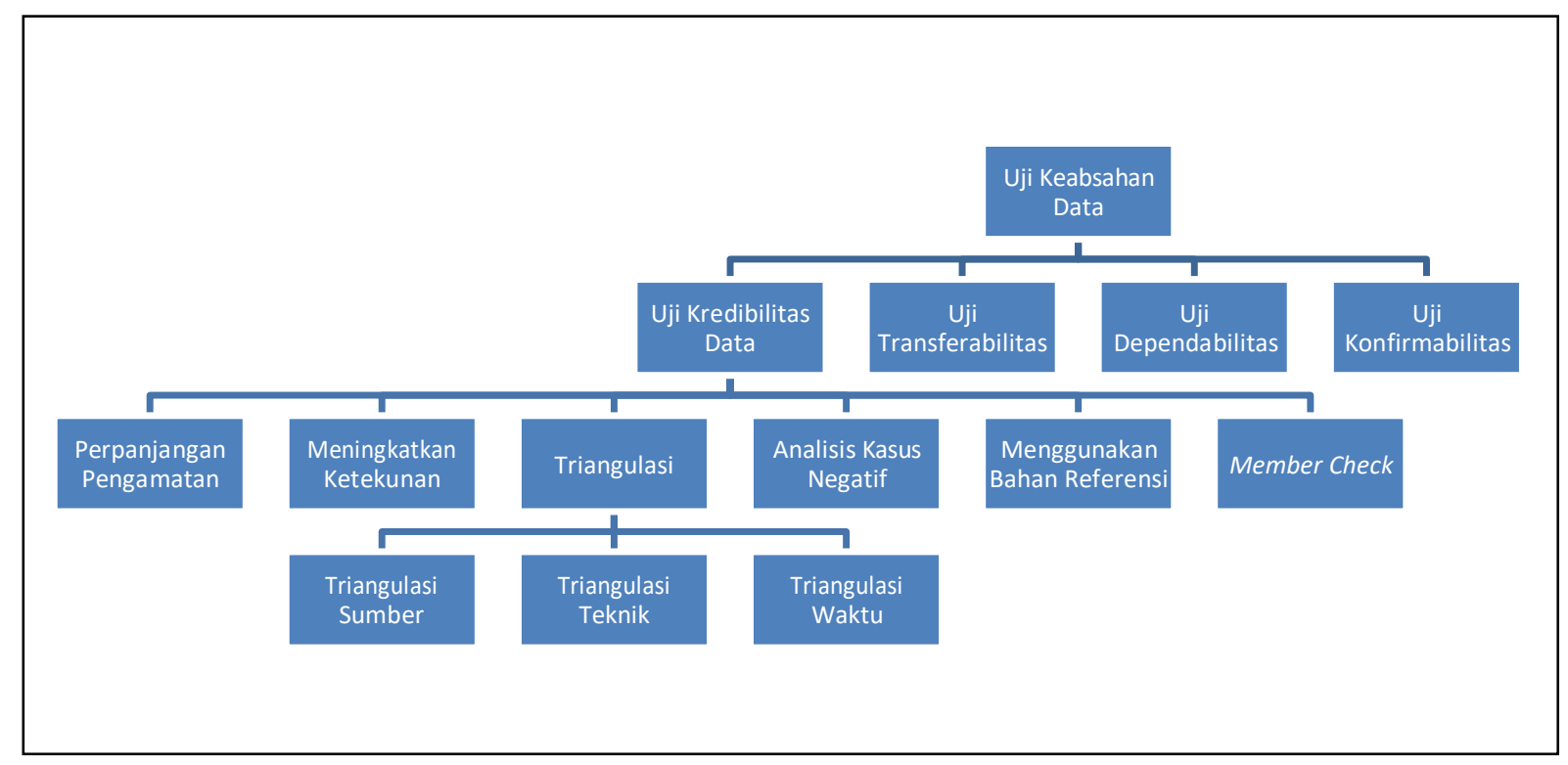

Gambar 1. Uji Keabsahan Data dalam Penelitian Kualitatif 
bukan yang terkait dengan ketersediaan sarana dan prasarana kesehatan. Uji kredibilitas data atau kepercayaan data penelitian kualitatif terdiri atas perpanjangan pengamatan, meningkatkan ketekunan, triangulasi, analisis kasus negatif, menggunakan bahan referensi dan member check. ${ }^{3}$

a) Perpanjangan pengamatan

Pada tahap awal peneliti memasuki lapangan, peneliti masih dianggap sebagai orang asing, masih dicurigai, sehingga informasi yang diberikan belum lengkap, tidak mendalam, dan masih memungkinkan banyak hal yang dirahasiakan. Dengan perpanjangan pengamatan ini berarti hubungan peneliti dengan narasumber akan semakin terbentuk rapport, semakin akrab (tidak ada jarak lagi), semakin terbuka, saling mempercayai sehingga tidak ada informasi yang disembunyikan lagi. Apabila telah terbentuk rapport, maka telah terjadi kewajaran dalam penelitian, dimana kehadiran peneliti tidak lagi mengganggu perilaku yang dipelajari. ${ }^{2}$ Dalam perpanjangan pengamatan untuk menguji kredibilitas data penelitian, yaitu dengan cara melakukan pengamatan apakah data yang diperoleh sebelumnya itu benar atau tidak ketika dicek kembali ke lapangan. Bila setelah dicek kembali ke lapangan sudah benar, berarti sudah kredibel, maka waktu perpanjangan pengamatan dapat diakhiri oleh peneliti. Sebagai bentuk pembuktian bahwa peneliti telah melakukan uji kredibilitas, maka peneliti dapat melampirkan bukti dalam bentuk surat keterangan perpanjangan pengamatan dalam laporan penelitian. ${ }^{3}$

b) Meningkatkan ketekunan

Peneliti dapat meningkatkan ketekunan dalam bentuk pengecekan kembali apakah data yang telah ditemukan itu benar atau tidak, dengan cara melakukan pengamatan secara terus-menerus, membaca berbagai referensi buku maupun hasil penelitian atau dokumentasi yang terkait, sehingga wawasan peneliti akan semakin luas dan tajam. Sebagai contoh, ketika melihat sekelompok masyarakat yang sedang olahraga pagi, bagi sebagian orang aktivitas ini hanya sebagai sarana untuk memelihara kesehatan secara fisik, namun peneliti dapat memiliki pandangan yang berbeda setelah dilakukannya pencermatan secara mendalam, sehingga diketahui olahraga pagi itu merupakan sarana untuk transaksi bisnis. $^{3}$

c) Triangulasi

Sebuah konsep metodologis pada penelitian kualitatif yang perlu diketahui oleh peneliti kualitatif selanjutnya adalah teknik triangulasi. Tujuan triangulasi adalah untuk meningkatkan kekuatan teoritis, metodologis, maupun interpretatif dari penelitian kualitatif. Triangulasi diartikan juga sebagai kegiatan pengecekan data melalui beragam sumber, teknik, dan waktu. ${ }^{1,3}$

1) Triangulasi sumber

Triangulasi sumber dapat dilakukan dengan cara melakukan pengecekan data yang telah diperoleh melalui berbagai sumber. Sebagai contoh, untuk menguji kredibilitas data tentang gaya kepemimpinan menteri kesehatan, maka pengujian keabsahan terhadap data yang telah diperoleh dapat dilakukan kepada bawahan yang dipimpin, kepada atasan yang menugasi, dan kepada rekan kerja. Data dari ketiga sumber yang berbeda tersebut, tidak dapat dirata-ratakan seperti dalam penelitian kuantitatif, tetapi dapat dideskripsikan, dikategorisasikan, mana pandangan yang sama, yang berbeda, dan mana spesifik dari tiga sumber data tersebut. Data yang telah dianalisis tersebut dapat menghasilkan suatu kesimpulan yang selanjutnya dapat dilakukan kesepakatan (member check) dengan tiga sumber data tersebut. ${ }^{3}$

2) Triangulasi teknik

Triangulasi teknik dapat dilakukan dengan melakukan 
pengecekan data kepada sumber yang sama, namun dengan teknik yang berbeda. Misalnya data yang telah diperoleh melalui wawancara mendalam kepada informan A terkait persepsi, gagasan, harapan, sikap, gaya hidup, dan lingkungan masyarakat terhadap pengimplementasian kesehatan gratis, maka dilakukan pengecekan informasi kembali melalui observasi, ataupun dokumentasi kepada informan A tersebut, maupun sebaliknya. ${ }^{3}$

- Wawancara mendalam (indepth interview): sebagian besar sumber data penelitian kualitatif didasarkan pada wawancara mendalam, teknik ini menggunakan pertanyaan open-ended, dengan mengutamakan sikap etis terhadap informan yang sedang dipelajari. Data yang diperoleh berupa persepsi, pendapat, perasaan, dan pengetahuan. ${ }^{6,9,10,11}$

- Observasi (pengamatan): observasi merupakan salah satu dasar fundamental dari semua metode pengumpulan data dalam penelitian kualitatif, khususnya menyangkut ilmuilmu sosial dan perilaku manusia. Observasi ini dilakukan dengan pengamatan terhadap apa yang diteliti yang hasilnya dapat berupa gambaran yang ada di lapangan dalam bentuk sikap, tindakan, pembicaraan, maupun interaksi interpersonal. $^{9,12}$

- Dokumen: dokumen merupakan sumber data yang digunakan untuk melengkapi penelitian, baik berupa sumber tertulis, film, gambar, (foto), dan karya-karya monumental, yang semuanya itu memberikan informasi bagi proses penelitian. ${ }^{13,14}$

Apabila dengan berbagai teknik tersebut menghasilkan data yang berbeda-beda satu sama lainnya, peneliti dapat melakukan diskusi lebih lanjut kepada sumber data yang terkait hingga didapatkan kepastian dan kebenaran datanya. ${ }^{3}$

3) Triangulasi waktu

Triangulasi waktu dapat dilakukan dengan melakukan pengecekan kembali terhadap data kepada sumber dan tetap menggunaakan teknik yang sama, namun dengan waktu atau situasi yang berbeda. Sebagai contoh, ketika ingin mengidentifikasi faktor penghambat dan pendukung dari peningkatan pelayanan kesehatan di Pusat Kesehatan Masyarakat (Puskesmas), maka informan sebelumnya yang telah dilakukan wawancara mendalam, diulangi wawancaranya pada waktu atau situasi berbeda. Apabila hasil uji tetap menunjukkan data yang berbeda, peneliti dapat melakukannya secara berulang hingga ditemukan kepastian data. ${ }^{3}$

d) Analisis kasus negative

Kasus negatif merupakan suatu kondisi data/kasus yang berbeda dengan hasil penelitian. Analisis kasus negatif dapat dilakukan dengan melakukan pencarian data yang berbeda atau bahkan bertentangan dengan data yang telah ditemukan secara lebih mendalam. Uji ini bergantung pada seberapa besar kasus negatif, jika ada $99 \%$ orang mengatakan bahwa si A, pengedar narkoba, sedangkan 1\% menyatakan tidak (negatif), maka peneliti harus mencari tahu secara mendalam dan menemukan kepastian apakah 1\% kelompok ini benar atau tidak. Jika pada akhirnya yang $1 \%$ kelompok ini kemudian menyatakan bahwa si A adalah pengedar narkoba, berarti kasus negatifnya tidak ada lagi. Dengan demikian, temuan penelitian menjadi lebih kredibel. ${ }^{3}$ 
e) Menggunakan bahan referensi

Bahan referensi merupakan bagian dari pendukung untuk membuktikan data yang ditemukan oleh peneliti secara autentik. Sebagai contoh, data hasil wawancara mendalam dengan informan dilengkapi rekaman audio-visual saat dilakukannya wawancara mendalam. ${ }^{3}$

\section{f) Member check}

Member check merupakan suatu proses pengecekan data kepada sumber data. Adapaun tujuan dilakukannya member check yaitu agar informasi yang diperoleh dalam laporan penelitian memiliki kesesuaian dengan apa yang dimaksudkan oleh sumber data atau informan. Member check dapat dilakukan setelah berakhirnya satu periode pengumpulan data. Mekanismenya dapat dilakukan secara individual, yaitu peneliti menemui sumber data atau bertemu dalam forum diskusi kelompok. Pada proses ini data dapat ditambah, dikurangi, ataupun ditolak oleh sumber data hingga diperolehnya kesepakatan bersama, dapat berupa dokumen yang telah ditanda-tangani. ${ }^{3}$

\section{Uji Transferabilitas (Transferability)}

Dalam penelitian kuantitatif, transferabilitas disebut validitas eksternal yang terkait dengan konsep generalisasi data. Transferabilitas menunjukkan derajat ketepatan atau sejauh mana dapat diterapkannya hasil penelitian ke populasi dimana informan tersebut dipilih. Pada penelitian kualitatif, nilai transferabilitas tergantung pada pembaca, sampai sejauh mana hasil penelitian tersebut dapat diterapkan pada konteks dan situasi sosial yang lain. Jika pembaca memperoleh gambaran dan pemahaman jelas tentang laporan penelitian (konteks dan fokus penelitian), seperti mengenai gambaran kualitas pelayanan kesehatan praktik bidan mandiri di Kabupaten $\mathrm{X}$ secara jelas, maka hasil penelitian itu dapat dikatakan memiliki transferabilitas tinggi. ${ }^{3,15}$

\section{Uji Dependabilitas (Dependability)}

Dalam penelitian kuantitatif, dependabilitas disebut reliabilitas. Dikatakan memenuhi dependabilitas ketika peneliti berikutnya dapat mereplikasi rangkaian proses penelitian tersebut. Uji dependabilitas dapat dilakukan melalui kegiatan audit terhadap seluruh proses penelitian. Hasil penelitian tidak dapat dikatakan dependable jika peneliti tidak dapat membuktikan bahwa telah dilakukannya rangkaian proses penelitian secara nyata. ${ }^{3}$

Mekanisme uji dependabilitas dapat dilakukan melalui audit oleh auditor independen, atau pembimbing terhadap rangkaian proses penelitian. Sebagai contoh, bagaimana peneliti mulai menentukan masalah maupun fokus penelitian, misalnya terkait implementasi kebijakan Kawasan Tanpa Rokok (KTR), bagaimana menentukan sumber data yang dapat menjelaskan tentang KTR, bagaimana memasuki lapangan, bagaimana mekanisme pengumpulan data, bagaimana melakukan pemeriksaan keabsahan data, bagaimana melakukan analisis data, hingga bagaimana melakukan penarikan kesimpulan. Jika peneliti tidak mempunyai rekam jejak aktivitas lapangan/penelitiannya, maka dependabilitasnya dapat diragukan. ${ }^{3}$

\section{Uji Konfirmabilitas (Konfirmability)}

Dalam penelitian kuantitatif, konfirmabilitas disebut objektivitas, yaitu apabila hasil penelitian telah disepakati banyak orang. ${ }^{3}$

Konfirmabilitas dalam penelitian kualitatif lebih diartikan sebagai konsep intersubjektivitas (konsep transparansi), yang merupakan bentuk ketersediaan peneliti dalam mengungkapkan kepada publik mengenai bagaimana proses dan elemen-elemen dalam penelitiannya, yang selanjunya memberikan kesempatan kepada pihak lain untuk melakukan assessment/penilaian hasil temuannya sekaligus memperoleh persetujuan diantara pihak tersebut. ${ }^{15}$

Konfirmabilitas adalah suatu proses kriteria pemeriksaan, yaitu langkah apa yang dipilih oleh peneliti dalam melakukan konfirmasi hasil temuannya. Peneliti di bidang kesehatan masyarakat dapat melakukan konfirmabilitas dengan cara merefleksikan 
hasil temuan peneliti pada jurnal, konsultasi dengan peneliti ahli, peer review, atau mendesiminasikan hasil temuannya pada suatu konferensi untuk mendapatkan masukan dalam memperbaiki hasil temuannya, baik pada tingkat regional, nasional, maupun internasional yang terkait bidang kesehatan masyarakat. ${ }^{15}$

\section{KESIMPULAN}

Penelitian yang merupakan suatu kegiatan ilmiah perlu dilakukan secara benar dan tepat, sesuai dengan ciri keilmiahan yang dapat dipertanggungjawabkan. Pada penelitian kualitatif, salah satu bentuk pertanggungjawaban atas penelitian yang dilakukan yaitu harus melalui tahapan dalam pemeriksaan keabsahan data yang dapat dilakukan dengan uji kredibilitas, transferabilitas, dependabilitas, maupun konfirmabilitas.

\section{DAFTAR PUSTAKA}

1. Murti B. Desain dan Ukuran Sampel untuk Penelitian Kuantitatif dan Kualitatif di Bidang Kesehatan. Yogyakarta: Gadjah Mada University; 2013.

2. Ika. Jumlah Perokok Indonesia di Atas 15 Tahun Tinggi [Internet]. Tersedia pada: http://ugm.ac.id/id/berita/17409-jumlahperokok-indonesia-di-atas-15-tahuntinggi.

3. Sugiyono. Metode Penelitian Kualitatif. Untuk Penelitian yang Bersifat: Eksploratif, Enterpretif, Interaktif, dan Konstruktif. Bandung: Alfabeta; 2017.
4. Zamili M. Menghindari dari Bias: Praktik Triangulasi dan Kesahihan Riset Kualitatif. J Lisan Al-Hal. 2015; 7 (2): 283-302.

5. Rahmat PS. Penelitian Kualitatif. J Equilibrium. 2009; 5 (9): 1-8.

6. Hadi S. Pemeriksaan Keabsahan Data Penelitian Kualitatif pada Skripsi. J Ilmu Pendidik. 2016;22(1):74-9.

7. Bachri BS. Meyakinkan Validitas Data melalui Triangulasi pada Penelitian Kualitatif. J Teknol Pendidik. 2010;10( 1):46-62.

8. Mustari M dan Rahman MT. Pengantar Metode Penelitian. Yogyakarta: LaksBang Pressindo; 2012.

9. Raco JR. Metode Penelitian Kualitatif: Jenis, Karakteristik, dan Keunggulannya. Jakarta: PT Grasindo; 2010.

10. Denzin, Norman K YSL. The Sage Handbook of Qualitative Research. Yogyakarta: Pustaka Belajar; 2011.

11. Rachmawati IN. Pengumpulan Data dalam Penelitian Kualitatif: Wawancara. J Keperawatan Indonesia. 2007; 11 (1): 3540.

12. Hasanah H. Teknik-Teknik Observasi (Sebuah Alternatif Metode Pengumpulan Data Penelitian Kualitatif Ilmu-Ilmu Sosial). J at-Taqaddum. 2016; 8 (2): 2146.

13. Salim. Metodologi Penelitian Kualitatif. Bandung: Citapustaka Media; 2016.

14. Nilamsari N. Memahami Studi Dokumen dalam Penelitian Kualitatif. J Wacana. 2014; 8 (2): 177-181.

15. Afiyanti Y. Validitas dan Reliabilitas dalam Penelitian Kualitatif. J Keperawatan Indonesia. 2008;12 (2):137-141. 